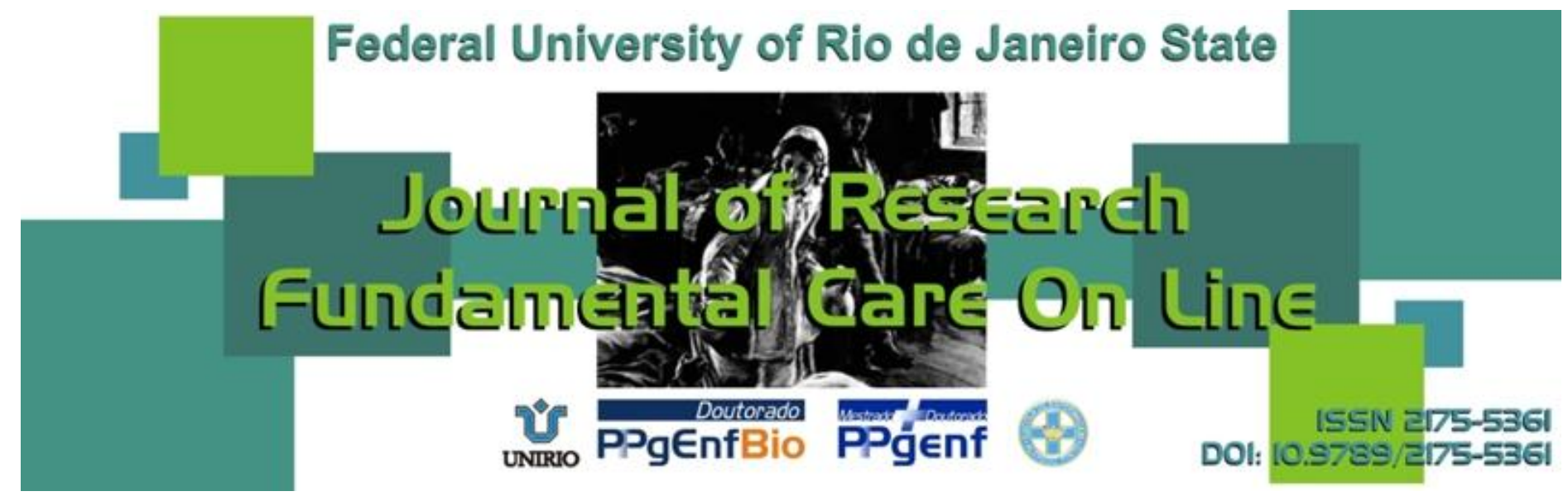

\title{
RESEARCH
}

\section{FULL DAY CARE TO WOMEN HEALTH}

DIA DO CUIDADO INTEGRAL À SAÚDE DAS MULHERES

\section{EL DIA DEL CUIDADO INTEGRAL A LA SALUD DE LAS MUJERES}

Jane Baptista Quitete ${ }^{1}$, Ricardo José Oliveira Mouta ${ }^{2}$, Rayanne dos Anjos Almeida ${ }^{3}$, Tatiana Leitão de Oliveira Jeronymo ${ }^{4}$, Fabiana Divina de Brito Amorim ${ }^{5}$

\section{ABSTRACT}

Objective: To report the profile of the users participating of an extension project. Method: This is a quantitative, descriptive and documentary study. Results: The action had as participants the nursing academics of the Federal Fluminense University/UFF/PURO and conducted in five Basic Unit Health chosen to cover most of the population in the city of Rio das Ostras/RJ. Were performed cytopathological exams, mammograms request and health education to 462 users. It appears that the involved population found in some situations of vulnerability in which women subjected. Conclusion: This activity was of great significance for the professional training of nursing students, providing them, opportunities to participate in the health activities, facilitating the sedimentation of the theoretical knowledge. Descriptors: Women health, Breast cancer, Gynecological examination, Vulnerability, Nursing.

\section{RESUMO}

Objetivo: Relatar o perfil das usuárias participantes de um projeto de extensão universitária. Método: Pesquisa documental, descritiva e quantitativa. Resultados: A ação extensionista contou com a participação de acadêmicos de enfermagem UFF/PURO, e foi realizada em cinco Unidades Básicas de Saúde escolhidas de forma a cobrir a maioria da população do município de Rio das Ostras/RJ. Foram atendidas 462 usuárias, sendo realizados exames citopatológicos, solicitação de mamografias e educação em saúde. Depreende-se que a população atendida encontra-se em algumas situações de vulnerabilidade que as mulheres estão submetidas. Conclusão: Atividade foi de grande importância para a formação profissional dos acadêmicos de enfermagem dando a eles a oportunidade de participar nas ações de saúde, facilitando a sedimentação do conhecimento teórico. Descritores: Saúde da mulher, Câncer de mama, Exame ginecológico, Vulnerabilidade, Enfermagem.

\section{RESUMEN}

Objetivo: Relatar el perfil de lãs mujeres que partiparon um proyecto de extensión universitaria. Metodo: Investigación documental, descriptiva e cuantitativa. Resultados: La actividad de extensión tuvo La participación de Estudiantes de enfermeria UFF/PURO y fue realizada em cinco UBS escogidas com La finalidad de captar a maioria de La poblacion de município de Rio das Ostras/RJ. Fueron atendidadas 462 mujeres a quienes se realizo examens citopatologicos, pedido de mamografias e educación en salud. Se concluye que La poblacion atendida se encuentra em situación de vulnerabilidad. Conclusión: La actividad realizada tuvo grande importância para La formación acadêmica de lós Estudiantes de enfermeria, quienes tuvieron oportunidad de participar de las acciones realizadas ló que facilita La sedimentación Del conocimiento teorico. Descriptores: Salud e la mujer, Cancer de senos, Examen ginecológico, Vulneravilidad, Enfermeria.

${ }^{1}$ Obstetrical Nurse. Doctoral candidate in nursing/UERJ. Professor of the course of nursing/UFF/Puro/RJ. Address: Rua Professor Carlos Góes, 58, apt. 602. Center. Campos dos Goytacazes. RJ. ZIP CODE: 28035 155. Tel.: 22 2722 0718. Email: janebq@oi.com.br. ${ }^{2}$ Obstetrics Nurse. Doctorate in nursing/UERJ. Woman Integral Health Assistance Program Manager/Rio das Ostras. E-mail: ricardomouta@hotamil.com. ${ }^{3}$ Nurse/UFF/Puro/RJ. E-mail: rayanne.dosanjos@yahoo.com. ${ }^{4}$ Student of the 10th period/UFF/Puro/RJ. E-mail: tatiana_jeronymo@hotmail.com. ${ }^{5}$ Student of the 10th period/UFF/Puro/RJ. E-mail: tatiana_jeronymo@hotmail.com. 


\section{INTRODUCTION}

The municipality of Rio das Ostras is located in the coastal lowlands of the State of Rio de Janeiro, and in 2010 had a population of approximately 105,676 inhabitants, of these, 35,301 of women of childbearing age (age group comprising women from 10 to 49 years of age). ${ }^{1-3}$ the percentage of women of childbearing age is $33.4 \%$ of the total female population, constituting a social segment important for health policymaking. ${ }^{4}$

According to the Program of Integral attention to women's health/WOMAN INTEGRAL HEALTH ASSISTANCE PROGRAM of Rio das Ostras, in 2010 were performed on cytological examinations 5621 colpo municipality and the goal agreed by the municipality was perform trace to $0.2 \%$ of the total number of women of childbearing age. However, for the year of 2011 was agreed $0.23 \%$ coverage of Pap smear for the municipality and, as we seen below, this index not be fulfilled if some interventions were not carried out.

The Pact data and compliance goals relate to the Covenant for life. ${ }^{5}$ The Covenant for life is a strategy of the Ministry of health, which reinforces the SUS public management movement by results, through the establishment of health priority commitments. In this case, the States and municipalities agree on the actions we deem necessary to achieve the proposed goals and objectives. Among the priorities is the control of cervical cancer of uterus and breast. ${ }^{6}$

The goals and targets related to this priority are $80 \%$ coverage for preventive examination of cervical cancer; Zoom in to $60 \%$ coverage of mammography, with a view to the early detection of breast cancer; perform the puncture in $100 \%$ of cases needed. ${ }^{7}$

The undergraduate program in nursing/Puro/UFF/RJ uses as a field of practice teaching and curricular internship health institutions of primary health care and hospital of the city of Rio das Ostras and therefore proposed to collaborate on health actions aimed at improving the quality of assistance offered to the population. These actions, shared with the students, could provide the critical and reflective learning from the local reality and their insertion in the world of work.

To this end, a partnership was signed between the Nursing course/Puro/UFF/RJ and the WOMAN INTEGRAL HEALTH ASSISTANCE PROGRAM/Rio das Ostras. The partnership between the health service and educational institutions is one of the proposals of the national policy of primary health care, in this, one of the municipal powers is to seek and facilitate partnerships with governmental and nongovernmental organizations. ${ }^{8}$ To this end, we have set the objective of this general intervention project: collaborate on the actions of promotion and prevention to the health of women in the municipality of Rio das Ostras.

The specific objectives were: to promote the health of the female population with a view to cervical cancer of uterus and breasts, sexually transmitted diseases, family planning, breastfeeding and neonatal screening; trace the cervical cancer of uterus and breasts, sexually transmitted diseases, diabetes mellitus, obesity and hypertension in the female population of the municipality of Rio das Ostras; immunize the female population against tetanus, hepatitis $B$, diphtheria, rubella and measles; facilitate the teaching-learning process of undergraduates of nursing care to women's health; provide the critical-reflexive vision student in front of the determinants of health of the female population; and trace profile of users participating in extensionists action.

J. res.: fundam. care. online 2013. out. / dez. 5(4):736-42 
Quitete JB, Mouta RJO, Almeida RS et al.

The target audience was estimated fifty (50) women of childbearing age in each of the 5 (five) health units, totaling two hundred and fifty (250) women. The purpose of this article is to make an account of experience on the implementation of an intervention project and some results obtained.

The program of Integral attention to women's health/WOMAN INTEGRAL HEALTH ASSISTANCE PROGRAM, implemented in Brazil in 1984, was the result of the fight of the women's movement and brought major innovations, among them, the women's approach in its completeness, exceeding the design of a mother-child program. ${ }^{4}$ In 2004, is launched the national policy of Attention to women's health, which proposes guidelines for humanization and the quality of care, outstanding issues in women's health care. This document incorporated a gender focus, completeness promotion health guiding principles seeks to consolidate the advances in the field of sexual and reproductive rights, emphasis on improving obstetric care, family planning, attention to unsafe abortion and to combat domestic and sexual violence. In addition, expanded actions in their plans of action for groups historically excluded from public policies, among them: lesbians, black Indies, among others. ${ }^{4.9}$

However, the epidemiological data reveal what Brazilian women sicken and die: abortion is the third cause of hospitalization (10.2\%), breast cancer is the leading cause of death by cancer $(15 \%)$ and the third place is with the cervical cancer of uterus $(6.6 \%)$; with the feminization of AIDS, we reached 10 women for every 15 men with AIDS; and the growing increase of chronic degenerative diseases arising from wear provided by excess of activities and responsibilities women of today. ${ }^{2}$
Full day care to...

Female vulnerability to certain diseases and causes of death is often, related not only to biological factors, but also with the situation of discrimination in society, poverty, domestic violence, among other issues. ${ }^{2,4.9}$

Female vulnerability can also related to access and quality of care in health services. Many women are entitled only to a sub-cidadania, since when has access to health services, such access eventually subject them to an institutional violence, i.e. health institutions determine what is possible or allowed to those users. This violence translates into delay in attendance (in long lines), fleeting attention within the offices, access to only some medications and/or technologies (many already considered second generation or even proscribed), and impersonality in attendance, among others. ${ }^{10}$

With regard specifically to cervical cancer of uterus and breast, it is known that, for the effective control of these pathologies are necessary actions that can ensure an integral attention to women at all levels, from prevention, diagnosis and treatment. 11. In Brazil, the main strategy used for early detection of cancer of the cervix is the realization of collecting material for smears cervico-vaginal examinations and micro flora, popularly known as preventive examination of the cervix, Pap smear, or oncotic cytology. With regard to breast cancer, early diagnosis actions consist of the clinical examination of the breasts of all women, as part of the gynecological exam by doctor or nurse; and mammography for all women from 40 years of age, with annual periodicity. ${ }^{9.11}$

The intervention action planning began in May of 2011, from the finding of a health problem that was the low offer gynecological examination for women of the municipality of Rio das Ostras. From then on, we started planning for the

J. res.: fundam. care. online 2013. out. / dez. 5(4):736-42 
moment very explanatory, followed by the moment. After the formalization and adoption of these milestones, we began the moment tacticaloperational with the definition of a plan of action: the definition of the population to be met, places of greater pent-up demand, definition of health units that behave the attendance of high demand, setting the weekday and time to completion of the event, publicizing the event for population, prediction of inputs and human resources, among others. Was also included in the action plan for the training of health professionals, teachers and students involved in extensionist action. ${ }^{6}$

\section{METHODOLOGY}

Documentary-type research, descriptive, quantitative. Data collected on the charts of women met during the action, extensionist's five units of health. The charts separated after the nursing consultation and data collection occurred in the months of November and December 2011 for the team project. The study population was 462 medical records. We used a form, checklist type, as a tool for data collection - this included the following variables:

(a) Age group;

(b) Time elapsed since the completion of the last Pap smear,

(c) Contraceptive method in use,

(d) Age of sexarca,

(e) Number of pregnancies, births and abortions,

(f) Type of childbirth,

(g) Clinical diagnosis of any sexually transmitted disease (STD) during the consultation of nursing;

(h) Realization of Pap test collection; and

(i) Mammogram request.

Data analysis conducted using national data provided by the Ministry of health, as well as thematic-related literature.

\section{RESULTS AND DISCUSSION}

Before the intervention, in October 2011, two courses: refresher course on cervical cancer and breasts for Nurses of basic attention and update course on syndromic approach of STDs to nurses and physicians in primary care. All participants of the courses have received CD with didactic material that included: the Ministry of health updated Manuals on control of cervical cancer and breast cancer; Sexual and reproductive rights; HIV/AIDS, hepatitis and other STDs; Prenatal and post-natal care; Nomenclature for cervical reports and proposed pipelines; professional law: COFEN Resolution about collecting Pap exam and the law of the professional practice of nursing; Flowchart for STD care for syndromic approach and two scientific papers on the themes in question. It is worth mentioning that this methodological step considered one of the municipal National policy skills of basic attention, i.e. to stimulate and facilitate training and permanent education of the professionals of the county health teams. ${ }^{3}$

The integral care day was held Saturday, October 22, 2011 in five basic health units of the municipality of Rio das Ostras: Seaside City Health Center, new hope Health Center, Health Centre extension of Woods, New City Health Center. These units work in the period from eight to 17:00 hours.

On this day, the following actions were carried out nursing consultation in order to track: uterine cervical cancer (colpo cytological material collection) and of the breast (clinical examination of breasts and/or mammogram request). In addition to the clinical actions were also undertaken actions of individual and collective health and education about cancer of the cervix of uterus, breast cancer, sexually transmitted

J. res.: fundam. care. online 2013. out. / dez. 5(4):736-42 
Quitete JB, Mouta RJO, Almeida RS et al.

diseases, contraception, and the supply of male and female condoms.

Other health actions scheduled to occur, but due to the excessive demand of women, were suspended. Were they: checking blood pressure, capillary blood glucose, weight, and height and waist circumference. Was also suspended the vaccination card update of users.

The team involved in the action was 12 (twelve) Nurses, 3 (three) doctors, 10 (ten) technical administrative staff, 13 (thirteen) spotter/nursing technicians, 5 (five) General services assistants, 1 (a), 2 (two) psychologist social workers-servers of the Municipal Health Secretariat of the municipality of Rio das Ostras. The team belonging to the PURO/UFF was 2 (two) teachers of the course of nursing and 14 (fourteen) students of the course of nursing.

Among the actions were performed clinical examinations, cytological colpo requested 421261 mammograms, computing 462 attendances. The profile of users met reveals that: $58 \%$ of users satisfied were aged 26 to 50 years old, although $21 \%$ of users were older than 61 years.

The time elapsed since the completion of the last Pap test was 1 year to $41 \%$ of women. The main strategy used for early detection of the disease in Brazil is through the tracing, which means perform the preventive exam (Pap smear) in women without symptoms of the disease, in order to identify those, which might constitute the disease in very early stage, when treatment can be most effective.

The recommended periodicity for carrying out this examination is, initially, one exam every year. In the case of two consecutive normal tests (with 1 year interval between them), the test should be done every 3 years. In the case of tests with results changed, the woman should follow the guidance provided by the accompanying doctor. ${ }^{11}$ It is worth mentioning that, the Pap test J. res.: fundam. care. online 2013. out. / dez. 5(4):736-42
Full day care to...

can performed in posts or health units, near the residence of women that have trained health professionals for this purpose.

The contraceptive method in use by women is a tubal sterilization in $22 \%$ of women, $11 \%$ oral anovulatory, and the male condom 6\%. In the national survey on demography and health, held in 1996, the concentration observed in the use of two contraceptive methods: tubal sterilization and birth control pills ( $40 \%$ and $21 \%$, respectively). The prevalence of tubal ligation is greater in regions where women have less schooling and most precarious socioeconomic conditions. ${ }^{4}$

In $37 \%$ of women answered, the first sexual intercourse - sexarca - occurred before the age of 17 years of age. Few services offer attention to sexual and reproductive health of adolescents. Teenage pregnancy has been subject of controversial discussions. While there is a reduction in the total fertility rate, fecundity in the Group of 15 to 19 years of age is increasing. This increase applies more in poorer, rural areas and in the population with less schooling. ${ }^{4}$ Among the factors that contribute to increased fecundity in this group is the increasingly early onset of puberty, as well as sexual activity. ${ }^{4}$

The incidence of at least one episode of abortion was $34 \%$ in the population studied. The situation of illegality in which the abortion performed in Brazil, affects the existence of reliable statistics that subsidize the implementation of public policies more accurate for the different regional realities and age groups, in which the unwanted pregnancy is most prevalent. $^{4.9}$

Abortion performed under conditions of risk is often accompanied by severe complications compounded by ignorance of such signals by most women and the delay in seeking health services, most of which is not trained for this kind of care. $^{4.9}$ 
Quitete JB, Mouta RJO, Almeida RS et al.

The fertility rate in $31 \%$ of women met was four or more pregnancies. Making a comparison with national data, obtained by the Brazilian Institute of Statistical Geography, we observed a decline in the fertility rate in the period from 2000 to 2006, having as main factors increased women's insertion in the labor market, better information on contraceptive methods and consequently an increasing usage. It is worth mentioning that towards women teens between 15 and 19 years had increased because of their social vulnerability. ${ }^{4}$

The Cesarean birth rate average is $42 \%$, representing a relatively high index. In addition, according to the Ministry of health, one of the regions of Brazil, the Southeast is the one that has the highest rate, with $47.5 \%$ in $2002 .^{12}$

It is necessary to emphasize that the vast majority of Cesarean section is not clinically necessary, i.e. there is no risk to the pregnant woman and neither for the baby. ${ }^{12}$ and along the prenatal consultations should be clarified powders and cons about each type of delivery, emphasizing the importance of physiological and humanized childbirth, so that the woman can choose which to, when there is such a possibility. The C-section indicated according to the clinical conditions of both the pregnant woman and the baby. Even with all these guidelines, some women still influenced by myths; by doctors that induce do $\mathrm{C}$-section for convenience and ease of access to the health service to be performing this procedure. ${ }^{9}$

It is worth mentioning that the $\mathrm{C}$-section considered as a major surgery, and like any surgery has risks of infection and complications, above all involves the whole hospital management for the use of the surgical Center, materials and equipment required to perform the procedure.

During the nursing consultation identified sexually transmitted diseases in $17 \%$ of users,
Full day care to...

among them: $6 \%$ of trichomoniasis, $2 \%$ of gardenerella vaginalis, and $9 \%$ of vaginal candidiasis. Sexually transmitted diseases (STDS) are among the most common public health problems worldwide. Recent estimates point to the occurrence of more than 10 million new sexually transmitted infections that can develop into symptomatic diseases such as urethritis, cervicitis, sores and genital warts, or remain asymptomatic. This, coupled with the high rate of self-medication, makes the bigger problem, since many of the cases do not receive adequate treatment and guidance, becoming sub-clinical, remaining transmitters and remaining fundamental links in the chain of transmission of infections. ${ }^{4.9}$

\section{CONCLUSION}

The results reveal some situations of vulnerability women subjected, among them the beginning of sexual life early, the high incidence of aborts, multiparity and the high rate of Cesarean section. These results formally introduced to the local managers, health teams involved in the action, and extensionist's population served.

We hope that through this study shares may subsidized in order to encourage the promotion, prevention and protection of health of the female population in the municipality in question, in order to minimize the causes that promote health, insecurity and encourage care for your body and your health.

The activity was of great importance for the vocational training of the nursing students, giving them opportunity to participate in the actions of health, interact with the users, besides facilitating the sedimentation of theoretical knowledge. The students were able to realize from promotion and prevention of the harms to health can improve the quality of life of women.

J. res.: fundam. care. online 2013. out. / dez. 5(4):736-42 
Quitete JB, Mouta RJO, Almeida RS et al.

\section{REFERENCES}

1. Ministério da Saúde (BR). Sistema de Informação Nacional de Saúde. Cadernos do Pacto pela Saúde Rio das Ostras. Brasília (DF): DATASUS; 2010/2011. [citado em 03 dez 2011]. Disponível em: URL: http://www2.datasus.gov.br.

2. Ministério da Saúde (BR). Painel de indicadores do SUS $\mathrm{n}^{\circ}$ 2. Temático Saúde da Mulher. Secretaria de Gestão Estratégica e Participativa, Departamento de Monitoramento e Avaliação da Gestão do SUS. Brasília; 2010.

3. Ministério da Saúde (BR). Secretaria de Gestão Estratégica e Participativa. $1^{\circ}$ Seminário de Gestão Participativa em Saúde da Região da Baixada Litorânea do Rio de Janeiro. Brasília; 2007.

4. Ministério da Saúde (BR). Política Nacional de Atenção à Saúde da Mulher: princípios e diretrizes. Secretaria de Atenção à Saúde, Departamento de Ações Programáticas Estratégicas. Brasília; 2009.

5. Ministério da Saúde (BR). Portaria GM/MS $\mathrm{n}^{\circ} 325$, de 21 de fevereiro de 2008, que trata do Pacto pela vida. Brasília (DF); 2008. [citado em 03 dez 2011]. Disponível em: URL: http: / / portal.saude.gov.br

6. Campos GW et al. Tratado de saúde coletiva. São Paulo (SP): Hucitec; 2006.

7. Ministério da Saúde (BR). II Plano Nacional de Políticas para as Mulheres. Secretaria Especial de Políticas para as Mulheres. Brasília; 2008.

8. Ministério da Saúde (BR). Política Nacional de Atenção Básica. $4^{\text {a }}$ Ed. Brasília; 2007.

9. Narchi NZ, Fernandes RAQ, organizadoras. Enfermagem e saúde da mulher. Barueri (SP): Manole; 2007.

10. Sanabria E. From sub-to super-citizens: sex hormonies and the body politic in Brazil. Ethnos 2010; 75(4): 377-401.
Full day care to...

11. Ministério da Saúde (BR). Controle dos cânceres do colo do útero e da mama/Secretaria de Atenção à Saúde, Departamento de Atenção Básica. Cadernos de Atenção Básica n. 13, Série A. Normas e Manuais Técnicos. Brasília; 2006.

12. Rattner D. Parto normal ou cesárea? O que toda mulher deve saber (e todo homem também). Interface (Botucatu) [periódico on line] 2005 ago; [citado 07 Mai 2012]; 9(17). Disponível em: http://www.scielo.br/scielo.

\section{Received on: 03/09/2012}

Reviews required: no

Approved on: 27/02/2013

Published on: 01/10/2013 